\title{
Study on gas exchange and antioxidant system of solanaceous species under water logged conditions
}

\section{KM Kumar, KB Sujatha, V Rajashree \& MK Kalarani}

\section{Journal of Agriculture and Ecology}

ISSN: 2456-9410

Volume: 6

Journal of Agriculture and Ecology (2018) 6: 54-63 http://doi.org/10.53911/JAE.2018.6207

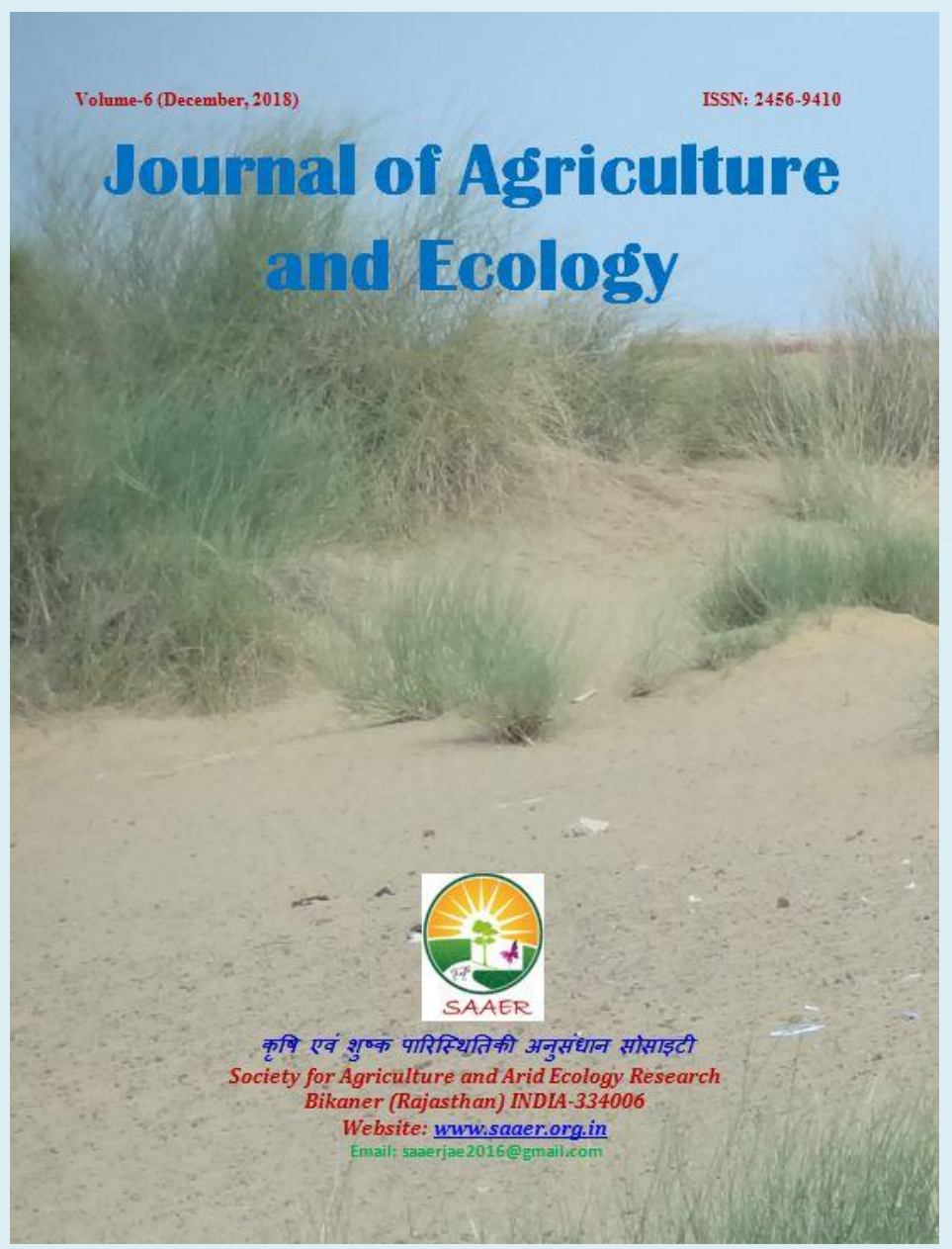




\title{
Study on gas exchange and antioxidant system of solanaceous species under water logged conditions
}

\author{
KM Kumar ${ }^{1} \not$, KB Sujatha ${ }^{2}$, V Rajashree ${ }^{2} \&$ MK Kalarani ${ }^{3}$ \\ ${ }^{I}$ Department of Crop Physiology, Tamil Nadu Agricultural University, Coimbatore. \\ ${ }^{2}$ Department of Fruit Crops, Tamil Nadu Agricultural University, Coimbatore. \\ ${ }^{3}$ Tapioca and Castor Research Station, Tamil Nadu Agricultural University, Yethapur
}

Corresponding author: KM Kumar, E-mail: manoagri900@gmail.com

\begin{tabular}{l}
\hline Article Info \\
\hline Article history \\
Received: 20 August 2018 \\
Accepted: 26 August 2018 \\
Available online: 27 \\
November 2018 \\
\hline
\end{tabular}

Key Words:

Photosynthetic activity, stomatal conductance flooding stress solanum spp., antioxidants, catalase, peroxidase, MDA.

\begin{abstract}
The aim of our work is to study gas exchange and antioxidant system in nine wild solanaceous species Solanum indicum, Solanum macrocarpon, Solanum acculeatissimum, Solanum sysimbrifolium, Solanum nigrum, Solanum viarum, Solanum insimum Solanum torvum, and Solanum macranthum under water logging condition. Experiments were laid in factorial completely randomized design with three replications. Photosynthesis and stomatal conductance decreased and closure of stomata was quick during flooding conditions in all the Solanum species. Species Solanum torvum performed photosynthetically better under flooding and also had better stomatal conductance. The antioxidants like SOD, catalase and peroxidase activity was significantly increased during the period of waterlogging and lipid peroxidation (MDA) content was decreased in tolerant Solanum species. An increase in the some parameters associated with oxidative stress, namely peroxides production, lipid peroxidation, and electrolyte leakage, reveals that root oxygen deficiency caused photooxidative damage in all rootstocks of solanaceous species. The ability to maintain a balance between the formation and detoxification of activated oxygen species appeared likely to increase the survival potential and the tolerance of the plants against varying oxidative stress. On basis of our observation, we conclude that species with higher photosynthetic rate and antioxidant system had improved waterlogging stress tolerance.
\end{abstract}

Copyright (C2018 Kumar et al., This is an open access article published under the terms of the Creative Commons Attribution License, which permits unrestricted use, distribution, and reproduction in any medium, provided the original work is properly cited.

Preferred citation: Kumar KM, Sujatha KB, Rajashree V \& Kalarani MK. 2018. Study on gas exchange and antioxidant system of solanaceous species under water logged conditions. Journal of Agriculture and Ecology, 6: 54-63; http://doi.org/10.53911/JAE.2018.6207.

\section{Introduction}

Horticultural crops particularly vegetable crops are sensitive to both drought and flood.
King et al. (2010) and Schwarz et al. (2010) reported that biotic and abiotic stresses are capable of markedly reducing crop productivity and thus cause severe constraints 
to growth. The Solanaceous crops are widely known as the nightshade family and are well known popular vegetable family which includes genera Solanum (potato and eggplant), Lycopersicon (tomato), and Capsicum (pepper). The damages caused by the unseasonal rains and sudden flooding must be minimized for better crop productivity. The plants growing on the waterlogged soil face the stressful environment in terms of availability of oxygen, which could be hypoxia (deficiency of $\mathrm{O}_{2}$ ) or anoxia (absence of $\mathrm{O}_{2}$ ). Even it changes the physico-chemical properties of soil like $\mathrm{pH}$, redox potential and available oxygen level. As $\mathrm{H}_{2} \mathrm{O}_{2}$ is potentially damaging, there are cellular antioxidant mechanisms that remove it very efficiently (Corpas et al. 2001). It is accepted that biotic and abiotic stresses, like hypoxia and anoxia, led to a change in $\mathrm{H} 2 \mathrm{O} 2$ production (Alscher et al. 1997; Blokhina et al. 2001; Apel \& Hirt 2004). The intracellular level of $\mathrm{H} 2 \mathrm{O} 2$ is regulated by a wide range of enzymes, the most important being catalase and peroxidases (Prasad et al. 1995). In our previous work with barley plants subjected for $120 \mathrm{~h}$ to soil flooding, we showed increased formation of ROS and restricted ability of antioxidative defense system under hypoxic conditions (Yordanova et al. 2004). In plants decrease in membrane integrity, as measured by electrolyte leakage (Chirkova et al. 1991) and activation of lipid peroxidation (Crawford et al. 1994; Crawford \& Braendle 1996) were detected like a symptom of injury caused by increased formation of ROS and integrity of the photosynthetic machinery and antioxidant activity. Among solanaceous species, brinjal was found to be the hardy plant which could survive under moderate edaphic and climatic stresses. The hypothesis to test in this work was whether there is a relationship between photosynthetic activity and the ability to tolerate flooding in different solanaceous species. Leaf injury, chlorophyll content, leafgas exchange and chlorophyll fluorescence parameters were used to correlate tolerance and integrity of the photosynthetic machinery and antioxidant activity. The present work was carried out with an objective to study the gas exchange and antioxidant system of solanaceous species under waterlogged condition.

\section{Materials and Methods}

Solanaceous wild species (viz., Solanum indicum, Solanum macrocarpon, Solanum acculeatissimum, Solanum sysimbrifolium, Solanum nigrum, Solanum viarum, Solanum insimum Solanum torvum and Solanum macranthum were selected for the study and raised in portrays. Forty days old seedlings were transplanted and flooding was given in submergence tank in the Department of Crop Physiology, Tamil Nadu Agricultural University, Coimbatore during 2017 to 2018. The morpho-physiological, biochemical and yield traits were recorded at vegetative stage after seven days of flooding. The data were statistically analyzed and the results are presented with suitable tables. The plants were divided into two groups at vegetative stage. One group of potted plants was subjected to flooding by submerging them in fabricated tank filled with water. The water level was maintained at $5 \mathrm{~cm}$ above the soil surface. The flooding was imposed for a period of 7 days. At the end of this period, the 
water removed from the tank and was allowed to recover. The one group of plants was grown under normal conditions as control. Certain parameters were taken for finding their tolerance under flooding condition. The fully expanded healthy leaf ( $4^{\text {th }}$ from top) was used for measurement of photosynthetic rate, Transpiration rate; Stomatal conductance was measured using portable photosynthesis system (LI-6400XT, Licor Inc, Nebraska, USA) and expressed as $\mu \mathrm{mol} \mathrm{CO}_{2} \mathrm{~m}^{-2} \mathrm{~s}^{-1}$. Transpiration rates expressed in $\mathrm{mmol}_{2} \mathrm{O} \mathrm{m}^{-}$ $2 \mathrm{~s}^{-1}$ Stomatal conductance and expressed as mol $\mathrm{H}_{2} \mathrm{O} \mathrm{m}^{-2} \mathrm{~s}^{-1}$. Adventitious root formation was counted on the basis of number of roots produced above soil surface after imposing flooding for 7 days. The numbers of adventitious roots were recorded at the $7^{\text {th }}$ day of flooding. Antioxidant enzyme were also analyzed like catalase was estimated according to Teranishi et al. (1974) and expressed as $\mu \mathrm{g}$ of $\mathrm{H}_{2} \mathrm{O}_{2}$ reduced $\min ^{-1} \mathrm{~g}^{-1}$ fresh weight. Peroxidase activity was determined and was expressed as change in OD value at $430 \mathrm{~nm} \mathrm{~g}^{-1} \min ^{-1}$ according to Perur (1962) and Angelini et al. (1990). Lipid peroxidation is analyzed by estimating malondialdehyde (MDA) content (Heath \& Packer 1968) after seven days of flooding treatment in solanaceous species.

\section{Results and Discussion}

Decreasing photosynthetic rate $(\mathrm{Pn})$ is a common response of plants to abiotic stress. Consequently, the factors that affect photosynthesis are likely to influence plant health and production (Walker 1992). In the present study, photosynthetic rate responded differently to flooding, based on relative flooding tolerance of each species. Normally, photosynthetic rate has reduced during flooding condition compared to control. Among the nine Solanum species $S$. sysimbrifolium has recorded significantly higher photosynthetic rate of $18.23 \mu \mathrm{mol} \mathrm{CO}_{2}$ $\mathrm{m}^{-2} \mathrm{~s}^{-1}$ for control and $12.32 \mu \mathrm{mol} \mathrm{CO} \mathrm{m}^{-2} \mathrm{~s}^{-1}$ for the flooding condition followed by $S$. nigrum recorded $17.07 \mu \mathrm{mol} \mathrm{CO} \mathrm{CO}^{-2} \mathrm{~s}^{-1}$ while during flooding S.nigrum recorded least photosynthetic rate of $8.21 \mu \mathrm{mol} \mathrm{CO}_{2} \mathrm{~m}^{-2} \mathrm{~s}^{-}$ ${ }^{1}$ under flooding .The Solanum species S.torvum recorded highest photosynthetic rate 14.59 $\mu \mathrm{mol} \quad \mathrm{CO}_{2} \quad \mathrm{~m}^{-2} \mathrm{~s}^{-1}$ under flooding condition (Table 1). Photosynthetic limitations can result from a number of factors. The photosynthesis rate is dependent on stomata and the photosynthetic machinery within the leaf, such as chlorophyll, thylakoid membrane complexes and stromal enzymes for $\mathrm{CO}_{2}$ reduction (Baker 2008; Farquhar \& Sharkey, 1982). The changes in the activity of some antioxidative enzymes (superoxide dismutase, catalase and peroxidase) and some indices related to structural and functional membrane stability, as measured by electrolyte leakage, lipid peroxidation and increased level of hydrogen peroxide explain that flooding led to oxidative stress that could be another reason for the observed inhibition of photosynthesis and this was explicated in the results found in barley (Yordanova et al., 2004) tomato (Else et al., 2008). These collective factors effect of decreasing the photosynthetic rate against flooding resulted in a decline in the rate of crop growth, net assimilation, and leaf expansion of plants. The loss of balance between the production of reactive oxygen species and the antioxidant defense inhibits 
the photosynthetic abilities of the plant Reddy et al. (2004).

Table 1. Effect of vegetative stage flooding on photosynthetic rate $\left(\mu \mathrm{mol} \mathrm{CO} \mathrm{m}^{-2} \mathrm{~s}^{-1}\right)$

\begin{tabular}{|c|c|c|c|}
\hline \multirow{2}{*}{ Solanum spp. } & \multicolumn{3}{|c|}{ Photosynthetic rate $\left(\mu \mathrm{mol} \mathrm{CO} \mathrm{m}^{-2} \mathrm{~s}^{-1}\right)$} \\
\hline & Control & flooding & Mean \\
\hline Solanum indicum & 15.06 & 9.22 & 12.14 \\
\hline Solanum macrocarpon & 14.25 & 9.63 & 11.94 \\
\hline Solanum acculeatissimum & 16.25 & 13.69 & 14.97 \\
\hline Solanum sysimbrifolium & 18.23 & 12.32 & 15.28 \\
\hline Solanum nigrum & 17.07 & 8.21 & 12.94 \\
\hline Solanum viarum & 14.73 & 8.82 & 11.47 \\
\hline Solanum insimum & 15.02 & 9.46 & 12.24 \\
\hline Solanum torvum & 16.56 & 14.59 & 15.58 \\
\hline Solanum macranthum & 16.25 & 9.12 & 12.69 \\
\hline \multirow[t]{2}{*}{ Mean } & 15.94 & 10.90 & 13.42 \\
\hline & $\mathrm{T}$ & $\mathrm{S}$ & SXT \\
\hline SEd & 0.079 & 0.167 & 0.239 \\
\hline $\mathrm{CD}(0.05 \%)$ & 0.162 & 0.343 & 0.486 \\
\hline
\end{tabular}

Stomatal closure can be particularly critical since it often reduces carbon assimilation due to loss of turgidity. The least stomatal conductance in $S$. sysimbrifolium was $\left(0.87 \mathrm{~mol} \mathrm{H}_{2} \mathrm{O} \mathrm{m}^{-2} \mathrm{~s}^{-1}\right)$ and in S.torvum, it was $\left(0.82 \mathrm{~mol} \mathrm{H}_{2} \mathrm{O} \mathrm{m}^{-2} \mathrm{~s}^{-1}\right)$ under control condition followed by $S$. macrocarpon recording 0.77 mol $\mathrm{H}_{2} \mathrm{O} \mathrm{m} \mathrm{m}^{-2} \mathrm{~s}^{-1}$. Under flooding $S$. torvum recorded higher stomatal conductance of 0.79 mol $\mathrm{H}_{2} \mathrm{O} \mathrm{m}^{-2} \mathrm{~s}^{-1}$ and it was least in $S$. nigrum (0.69 $\mathrm{mol} \mathrm{H}_{2} \mathrm{O} \mathrm{m}^{-2} \mathrm{~s}^{-1}$ ) (Table 2). This may be due to one or more signals generated directly or indirectly by roots are presumed to be responsible for initiating stomatal closure in flooded plants (Jackson 2002). In pea (Pisum sativum), an accumulation message in the form of ABA accretion in leaves due to Table 2. Effect of vegetative stage flooding stress on stomatal conductance $\left(\mathrm{mol} \mathrm{H}_{2} \mathrm{O} \mathrm{m} \mathrm{m}^{-2} \mathrm{~s}^{-1}\right.$.) in Solanum spp.

\begin{tabular}{lccc}
\hline \multirow{2}{*}{ Solanum spp. } & \multicolumn{3}{c}{ Stomatal conductance $\left(\mathrm{mol} \mathrm{H}_{2} \mathrm{O} \mathrm{m}^{-2} \mathrm{~s}^{-1}.\right)$} \\
\cline { 2 - 4 } & Control & flooding & Mean \\
\hline Solanum indicum & 0.71 & 0.58 & 0.65 \\
Solanum macrocarpon & 0.65 & 0.70 & 0.74
\end{tabular}




\begin{tabular}{lccc}
\hline & & & \\
Solanum acculeatissimum & 0.77 & 0.59 & 0.61 \\
Solanum sysimbrifolium & 0.87 & 0.77 & 0.82 \\
Solanum nigrum & 0.63 & 0.30 & 0.50 \\
Solanum viarum & 0.69 & 0.42 & 0.52 \\
Solanum insimum & 0.69 & 0.42 & 0.56 \\
Solanum torvum & 0.82 & 0.79 & 0.81 \\
Solanum macranthum & 0.69 & 0.31 & 0.49 \\
\hline Mean & 0.72 & 0.54 & 0.63 \\
& $\mathrm{~T}$ & $\mathrm{~S}$ & $\mathrm{TXS}$ \\
SEd & 0.004 & 0.009 & 0.013 \\
CD $(0.05 \%)$ & 0.009 & 0.019 & 0.028 \\
\hline
\end{tabular}

Table 3. Effect of vegetative stage flooding on transpiration rate $\left(\mathrm{mmol} \mathrm{H}_{2} \mathrm{O} \mathrm{m}^{-2} \mathrm{~S}\right)$ of Solanum spp.

\begin{tabular}{lccc}
\hline \multirow{2}{*}{ Solanum spp. } & \multicolumn{3}{c}{ Transpiration rate $\left(\mathrm{mmol} \mathrm{H}_{2} \mathrm{O} \mathrm{m}^{-2} \mathrm{~s}^{-1}\right)$} \\
\cline { 2 - 4 } & Control & Flooding & Mean \\
\hline Solanum indicum & 16.25 & 11.36 & 13.74 \\
Solanum macrocarpon & 14.21 & 13.56 & 15.56 \\
Solanum acculeatissimum & 18.22 & 17.56 & 17.89 \\
Solanum sysimbrifolium & 18.21 & 16.53 & 17.37 \\
Solanum nigrum & 16.32 & 11.23 & 13.84 \\
Solanum viarum & 17.56 & 13.52 & 15.54 \\
Solanum insimum & 15.21 & 12.21 & 13.71 \\
Solanum torvum & 18.25 & 18.02 & 18.14 \\
Solanum macranthum & 17.56 & 12.32 & 13.27 \\
Mean & 17.33 & 14.68 & 16.01 \\
& $\mathrm{~T}$ & $\mathrm{~S}$ & $\mathrm{TXS}$ \\
SEd & 0.123 & 0.261 & 0.370 \\
CD $(0.05 \%)$ & 0.250 & 0.530 & 0.750 \\
\hline
\end{tabular}

\section{Antioxidant activity}

Plant use antioxidant enzymes to detoxify reactive oxygen species and mitigate oxidative stress-induced damage under flooding condition. The main ROS (Reactive oxygen species) are superoxide, single oxygen, hydrogen peroxide and hydroxyl radical, which are very reactive and provokes the damage to lipid membranes proteins, lipid peroxidation of organelles and cellular membranes enzymes lead to affecting cellular functioning and resulting in ultimate membrane leakage and cell lysis and also cause oxidative damage to DNA (Foyer et al. 1994; Noctor \& Foyer 1998). To control the level of ROS, lipid peroxidation and to protect cells under stress conditions, plant tissues utilizes the ROS scavenging enzymes, The role of antioxidant enzymes is considered as one of the main tolerance mechanisms as a response to different environmental extremes.

The plants have antioxidants like ascorbate, glutathione and tocopherols, and enzymes (i.e. peroxidases, superoxide dismutase, glutathione reductase, catalase) 
with ability to scavenge ROS and regenerate the antioxidants (Asada 1987; Murchie \& Niyogi 2011). However, under any stress, ROS are overproduced that may reduce the scavenging capacity of the antioxidants, that generates the oxidative damage on the proteins of the photosynthetic apparatus (Yordanova et al. 2004; Goyal et al. 2017). Lipid peroxidation is a common feature of stressed plants Chugh et al. (2011) exposed seedlings of six genotypes of maize (two) drought-tolerant and (four) drought-sensitive to $72 \mathrm{~h}$ drought stress at two leaf stage. They noticed increase in lipid peroxidation in sensitive varieties while tolerant varieties did not show observable change and similar results were observed in the tolerant Solanum species taken for the present study (Fig 1). The present study revealed that the superoxide dismutase and peroxidase activity was observed to be significantly higher in all the Solanum species under flooding condition (Fig $2)$. The $S$. torvum and S. acculeafissimum showed a higher activity of superoxide dismutase (608 units $\mu \mathrm{g} \mathrm{g}^{-1}$ of protein and 512 units $\mu \mathrm{g} \mathrm{g}^{-1}$ of protein) (Table 4), peroxidase of 5.02 at $430 \mathrm{nmg}-1 \mathrm{~min}-1$ and 4.78 at 430 $\mathrm{nmg}^{-1} \mathrm{~min}^{-1}$ activity and less lipid peroxidation under flooding condition and their activity was lowest in $S$. nigrum and $S$. viarum(Fig 2 and Fig 3). The same trend was observed with the activity of catalase in these species that explain the capacity of tolerant species to enhance the antioxidant defense system.

Table 4. Effect of vegetative stage flooding stress on superoxide dismutase (enzyme unit $\mu \mathrm{g} \mathrm{g}^{-1}$ protein) in Solanum spp.

Superoxide dismutase

Solanum spp. (enzyme unit $\mu \mathrm{g} \mathrm{g}^{-1}$ protein)

\begin{tabular}{lccc} 
& Control & Flooding & Mean \\
\hline Solanum indicum & 250.1 & 360.70 & 305.40 \\
Solanum macrocarpon & 225.2 & 345.90 & 285.55 \\
Solanum acculeatissimum & 198.7 & 503.40 & 351.05 \\
Solanum sysimbrifolium & 212.4 & 428.70 & 320.55 \\
Solanum nigrum & 184.5 & 211.54 & 199.75 \\
Solanum viarum & 156.7 & 281.50 & 219.10 \\
Solanum insimum & 199.4 & 299.50 & 249.45 \\
Solanum torvum & 200.3 & 608.10 & 404.20 \\
Solanum macranthum & 195.6 & 215.02 & 203.57 \\
\hline Mean & 202.54 & 361.59 & 282.07 \\
SEd & $\mathrm{T}$ & $\mathrm{S}$ & $\mathrm{TXS}$ \\
CD (0.05) & 0.005 & 0.011 & 0.016 \\
\hline
\end{tabular}


Fig 1. Effect of flooding on vegetative stage on catalase ( $\mu$ g of $\mathrm{H}_{2} \mathrm{O}_{2}$ reduced $\min ^{-1} \mathrm{~g}^{-1}$ fresh weight) and peroxidase $\left(\Delta 430 \mathrm{~nm} \mathrm{~min}^{-1} \mathrm{~g}^{-1}\right)$ in Solanum spp.

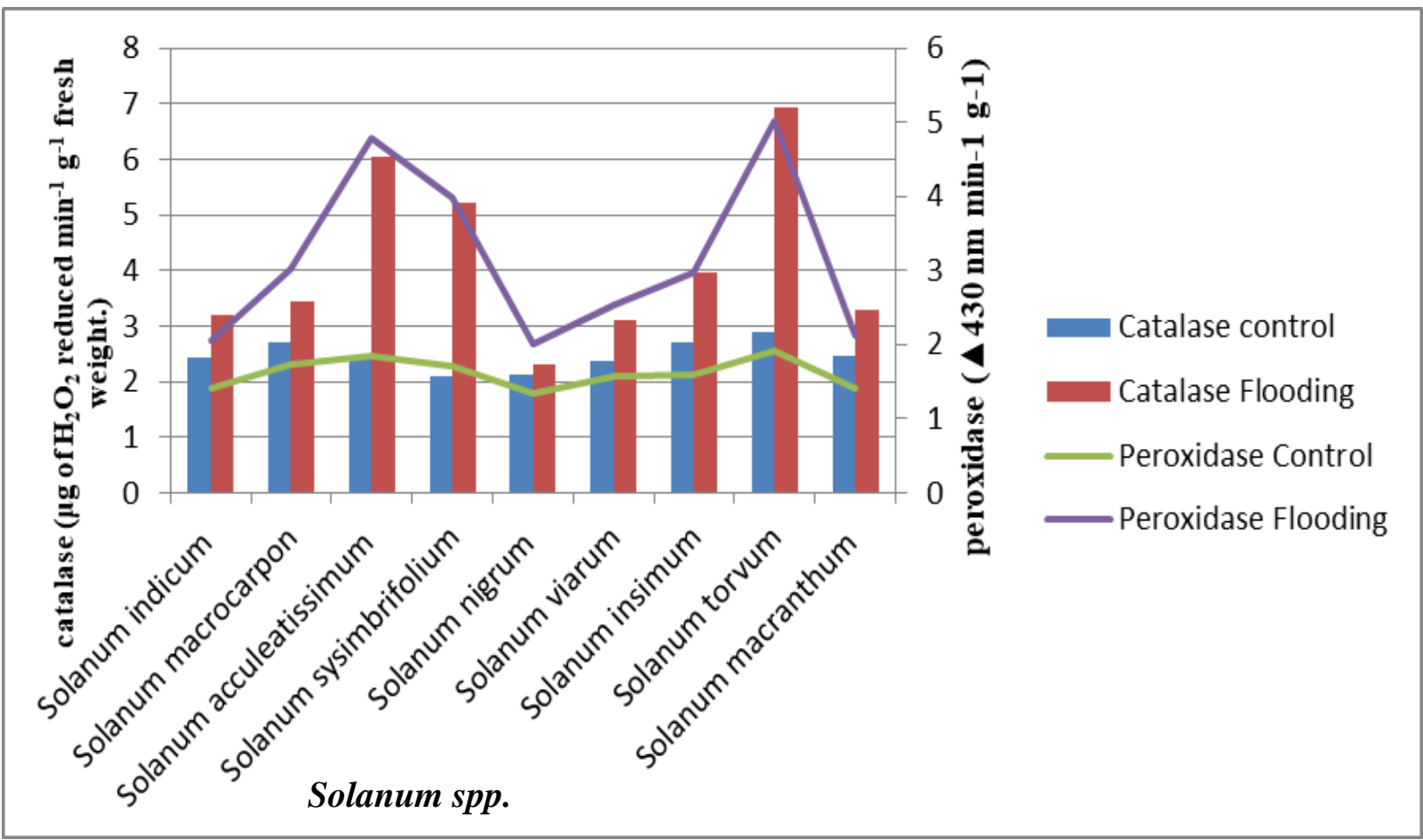

Fig. 2. Effect of vegetative stage flooding stress on lipid peroxidation by malondialdehyde (MDA) ( $\mu \mathrm{mol} / \mathrm{g}$ of fresh weight) in Solanum spp.

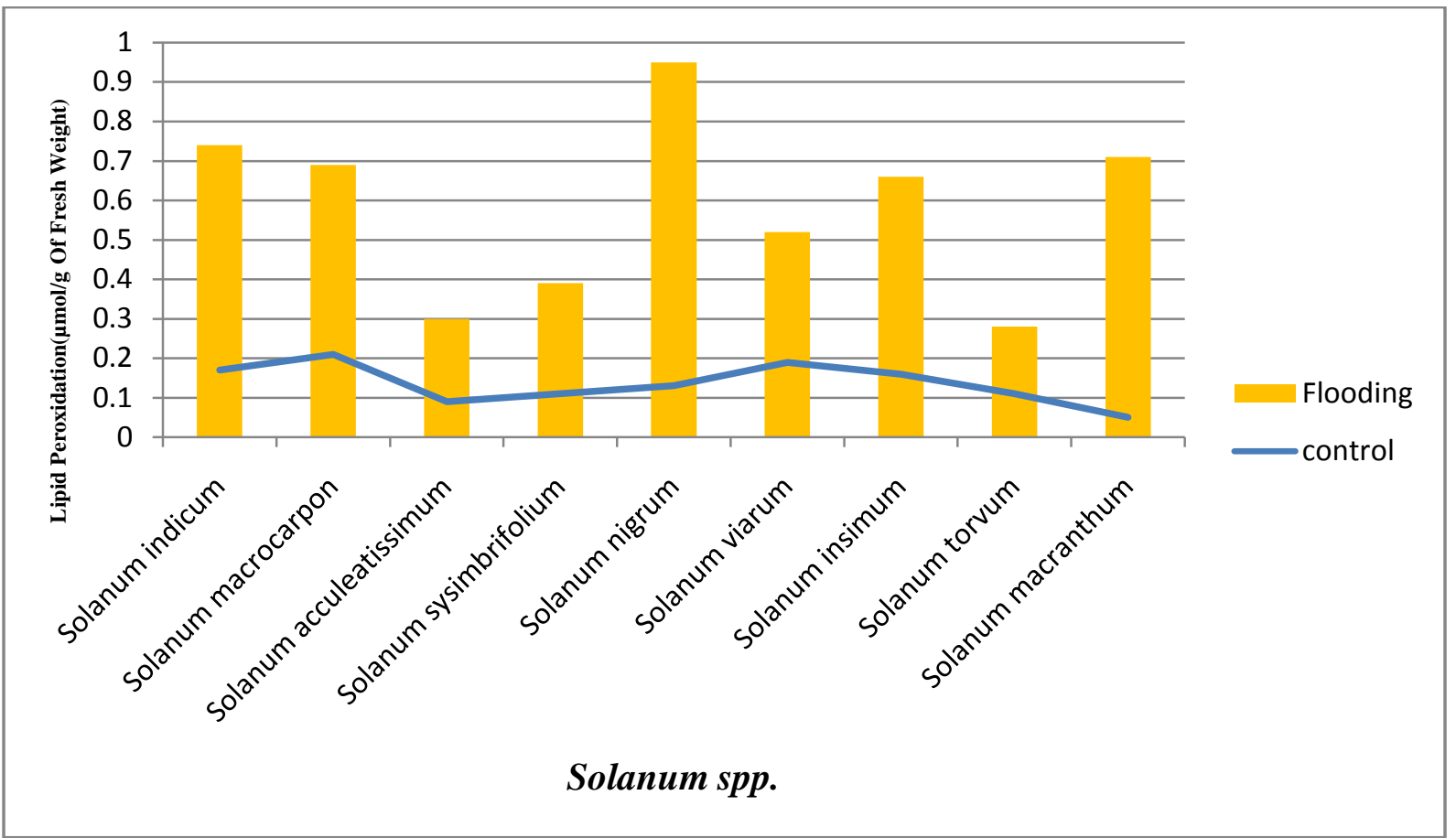




\section{Conclusion}

The result elucidate that water logging, in general, reduced the gas exchange and photosynthetic activity in all species to a considerable extent however there is a inbuilt tolerance ability in some species where the symptoms of flooding was not much pronounced ,especially, Solanum torvum where it had improved gas exchange and antioxidant activity under flooding as compared to the other plants and also have significantly increased photosynthetic activity, stomatal conductance, higher antioxidant activity (catalase and peroxidase) reduced the lipid peroxidation (MDA) contents among the solanaceous species under flooding.

\section{Acknowledgment}

Our sincere thanks to Dr. C. Narayanan kutty for providing the seeds.

\section{References}

Angelini R, Manes F \& Federico R. 1990. Spatial and functional correlation between diamine-oxidase and peroxidase activities and their dependence upon deetiolation and wounding in chick-pea stems. Planta, 182 (1): 89-96.

Asada K. 1987. Production and scavenging of active oxygen in photosynthesis. Photoinhibition, 227-287.

Baker NR. 2008. Chlorophyll fluorescence: a probe of photosynthesis in vivo. Annual Review of Plant Biology, 59: 89-113.

Chugh V, Kaur N \& Gupta AK. 2011. Evaluation of oxidative stress tolerance in maize (Zea mays L.) seedlings in response to drought.
Else MA, Coupland D, Dutton L \& Jackson MB. 2001. Decreased root hydraulic conductivity reduces leaf water potential, initiates stomatal closure and slows leaf expansion in flooded plants of castor oil (Ricinus communis) despite diminished delivery of ABA from the roots to shoots in xylem sap. Physiologia Plantarum, 111(1): 46-54.

Else MA, Janowiak F, Atkinson CJ \& Jackson MB. 2008. Root signals and stomatal closure in relation to photosynthesis, chlorophyll a fluorescence and adventitious rooting of flooded tomato plants. Annals of botany, 103(2): 313323.

Ezin V, Pena RDL \& Ahanchede A. 2010. Flooding tolerance of tomato genotypes during vegetative and reproductive stages. Brazilian Journal of Plant Physiology, 22(2): 131-142.

Farquhar GD \& Sharkey TD. 1982. Stomatal conductance and photosynthesis. Annual Review of Plant Physiology, 33(1): 317345.

Foyer CH, Lelandais M \& Kunert KJ. 1994. Photooxidative stress in plants. Physiologia Plantarum, 92(4): 696-717.

Ginoux G \& Laterrot H. 1991. Greffage de l'aubergine: reflexions sur le choix du portegreffe. PHM Revue Horticole, 321(1): 49-54.

Goyal P, Berwal MK, Praduman \& Chugh LK. 2017. Peroxidase actvity, its isozymes and deterioration of pearl 
millet [Pennisetum glaucum (L.) R. BR.] flour during storage. Journal of Agriculture and Ecology, 3: 42-51.

Heath RL \& Packer L. 1968. Photoperoxidation in isolated chloroplasts: I. Kinetics and stoichiometry of fatty acid peroxidation. Archives of biochemistry and biophysics, 125(1): 189-198.

Hetherington AM, Hunter MIS \& Crawford RM. 1982. Contrasting effects of anoxia on rhizome lipids in Iris species. Phytochemistry, 21(6): 1275-1278.

Jackson M \& Hall K. 1987. Early stomatal closure in waterlogged pea plants is mediated by abscisic acid in the absence of foliar water deficits. Plant, Cell \& Environment, 10(2): 121-130.

Jackson MB. 2002. Long-distance signalling from roots to shoots assessed: the flooding story. Journal of Experimental Botany, 53(367): 175-181.

Jokhan AD, Else MA \& Jackson MB. 1996. Delivery rates of abscisic acid in xylem sap of Ricinus communis L. plants subjected to part-drying of the soil. Journal of Experimental Botany, 47(10): 1595-1599.

Khah EM, Katsoulas N, Tchamitchian M \& Kittas C. 2012. Effect of grafting on eggplant leaf gas exchanges under Mediterranean greenhouse conditions. International Journal of Plant Production, 5(2): 121-134.

King SR, Davis AR, Zhang X \& Crosby K. 2010. Genetics, breeding and selection of rootstocks for Solanaceae and Cucurbitaceae. Scientia Horticulturae, 127(2): 106-111.

Lee JM. 1994. Cultivation of grafted vegetables I. Current status, grafting methods, and benefits. HortScience, 29(4): 235-239.

Murchie EH \& Niyogi KK. 2011. Manipulation of photoprotection to improve plant photosynthesis. Plant physiology, 155(1): 86-92.

Noctor G \& Foyer CH. 1998. Ascorbate and glutathione: keeping active oxygen under control. Annual review of plant biology, 49(1): 249-279.

Perur N. 1962. Measurement of peroxidase activity in plant leaf tissue. Current Science, 31(1): 17-18.

Premachandra GS, Saneoka H, Fujita K \& Ogata S. 1992. Leaf water relations, osmotic adjustment, cell membrane stability, epicuticular wax load and growth as affected by increasing water deficits in sorghum. Journal of Experimental Botany, 43(12): 15691576.

Reddy AR, Chaitanya KV \& Vivekanandan M. 2004. Drought-induced responses of photosynthesis and antioxidant metabolism in higher plants. Journal of plant physiology, 161(11): 1189-1202.

Rhodes D \& Samaras Y. 1994. Genetic control of osmoregulation in plants. Cellular and molecular physiology of cell volume regulation, 347-361. 
Schwarz D, Rouphael Y, Colla G \& Venema JH. 2010. Grafting as a tool to improve tolerance of vegetables to abiotic stresses: thermal stress, water stress and organic pollutants. Scientia Horticulturae, 127(2): 162-171.
Walker D. (1992). Energy, plants and man: Univ Science Books.

Yordanova RY, Christov KN \& Popova LP. 2004. Antioxidative enzymes in barley plants subjected to soil flooding. Environmental and Experimental Botany, 51(2): 93-101. 